\title{
Changes in Vital Signs and Laboratory Tests in Patients with Odontogenic Infections Requiring Hospitalization
}

\author{
Cambios en los Signos Vitales y Pruebas de Laboratorio en Pacientes \\ con Infecciones Odontogénicas que Requirieron Hospitalización
}

\author{
Eduardo P. Pavan'; Washington G. P. Rocha-Junior'; Hans-Albrecht Gitt² \& João Gualberto C. Luz ${ }^{3}$
}

PAVAN, E. P.; ROCHA-JUNIOR, W. G. P. ; GITT, H. A. \& LUZ, J. G. C. Changes in vital signs and laboratory tests in patients with odontogenic infections requiring hospitalization. Int. J. Odontostomat., 14(4):685-693, 2020.

\begin{abstract}
The purpose of this study was to evaluate the changes in vital signs and laboratory tests of patients with odontogenic infections who required hospitalization as well as checking their effectiveness in determining the severity of the case and possible correlations with the length of stay. Patients with odontogenic infections who required hospitalization were assessed prospectively between October 2016 and April 2018. The patients were divided into two groups considered as simple (Group 1) or complex (Group 2) cases according to the length of stay. The personal data, comorbidities, signs and symptoms, vital signs and laboratory tests were analyzed. In this study, 84 cases of maxillofacial infections were detected and 50 cases of odontogenic infections were included. There were significant increases in heart rate $(p=0.012)$, leukocytosis $(p=0.037)$, neutrophilia $(p=0.021)$, neutrophil/lymphocyte $(N / L)$ ratio $(p=0.044)$ and C-reactive protein $(C R P)$ levels $(p=$ 0.004 ) in Group 2. Additionally, there were positive correlations between the length of stay and the following variables: heart rate $(p=0.028)$, leukocytosis $(p=0.045)$, neutrophilia $(p=0.033), N / L$ ratio $(p=0.041)$ and CRP level $(p=0.003)$. The N/L ratio was found to have a greater value in regression analysis. It was concluded that there were significant increases in heart rate, leukocytosis, neutrophilia, N/L ratio and CRP levels for the complex cases. There were also positive correlations between the length of stay and the following variables: heart rate, leukocytosis, neutrophilia, N/L ratio and CRP level.
\end{abstract}

KEY WORDS: odontogenic infections, bacterial infections, hospitalization, vital signs, blood cell count.

\section{INTRODUCTION}

Odontogenic infections represent a large proportion of cases of infections involving the head and neck region. Most of the episodes can be treated in a simple way; however, when disseminated through fascial spaces, they can cause severe morbidity to the patient due to the anatomical proximity of the pharyngeal, cervical, thoracic and intracranial regions (Ylijoki et al., 2001; Sharma et al., 2014; Dogruel et al., 2017).

The attendingp professional may use clinical and laboratory data in an attempt to classify the case as simple or complex. The signs and symptoms vary considerably from local edema to a life-threatening condition, and despite the evolution of health services, the course of infection may be unpredictable and lead to severe complications or even death (Ylijoki et al.;
Camino Junior et al., 2014; Stathopoulos et al., 2016). Changes in vital signs such as heart rate, breathing rate, blood pressure, and temperature, may also be helpful. However, in some cases, such information may appear late or be insufficient for a precise diagnosis (Bali et al., 2017).

To estimate the clinical condition of the patient, laboratory tests, such as white blood cell count, and inflammatory markers, such as erythrocyte sedimentation rate (ESR) and C-reactive protein (CRP), are used (Aguiar et al., 2013). These data, which are associated with clinical examination, are determinant for assessing therapeutic efficacy, investigating infection levels and determining the duration of antibiotic use (Sharma et al.; Honda et al., 2016).

\footnotetext{
${ }^{1}$ Department of Oral and Maxillofacial Surgery, Hospital M. Dr. Arthur R. de Saboya, São Paulo, Brazil.

2 International College for Maxillo-Facial Surgery, Leipzig, Germany.

${ }^{3}$ Department of Oral and Maxillofacial Surgery, School of Dentistry, University of São Paulo, Brazil.
} 
The aim of this study was to evaluate the changes in vital signs and laboratory tests of patients with odontogenic infections who required hospitalization, and to verify their efficacy in determining the severity of the presented case and possible correlations with the length of stay.

\section{MATERIAL AND METHOD}

Patients diagnosed with odontogenic infections who needed hospitalization and were admitted to the Oral and Maxillofacial Surgery Clinic between October 2016 and April 2018 were prospectively evaluated. All of the patients who participated in the study provided informed consent. This study was approved by the Research Ethics Committee (Protocol No. 65834717.5.0000.0086).

Patients with a diagnosis of odontogenic infections whose clinical picture showed a need for hospital admission were included, regardless of age, sex or race. The following were excluded from the study: cases of infections that had nonodontogenic origins, cases of odontogenic infections treated on an outpatient basis, patients being treated by another service and attended for care and patients who refused to participate in the study.

For each patient, data regarding age, sex, risk factors (such as diabetes mellitus, smoking and drug use), signs and symptoms, affected fascial spaces, infection causing tooth, vital signs at admission, laboratory tests, conduct during hospitalization, and duration of hospital stay were obtained. Computed tomography scans were used to determine the spread of odontogenic infection to fascial spaces and their involvement. At the admission of patients, data on vital signs such as body temperature, heart rate, respiratory rate, and systolic and diastolic blood pressure were obtained. Additionally, data on laboratory tests such as leukocytes, neutrophils, Iymphocytes, neutrophil/ lymphocyte (N/L) ratio, CRP and ESR were obtained. These tests were again obtained 24 hours after surgical therapy and every 48 hours until discharge.

All patients were given the same surgical care, which included drainage of the infection in the fascial spaces involved and collection of secretions from the drainage for culture examination and bacterioscopy by the same surgical team. The most commonly used antibiotics for hospitalized patients on this service were ceftriaxone in combination with clindamycin. The need for artificial ventilation (intubation or tracheostomy) was decided with the emergency room medical clinic staff or the operating room anesthesia team according to the severity of the case. Hospital discharge was determined when the clinical parameters and/or laboratory values of the inflammatory markers presented an improved condition, showing the efficacy of the treatment.

Patients were divided into two groups considered as simple (Group 1) or complex (Group 2) cases according to the length of hospital stay. In Group 1, the hospital stay lasted up to three days, while in Group 2 the hospitalization time was greater than three days (Figs. 1 and 2) according to Mirochnik et al. (2017). The personal data, comorbidities, signs and symptoms, vital signs and laboratory tests were analyzed in relation to these two groups.

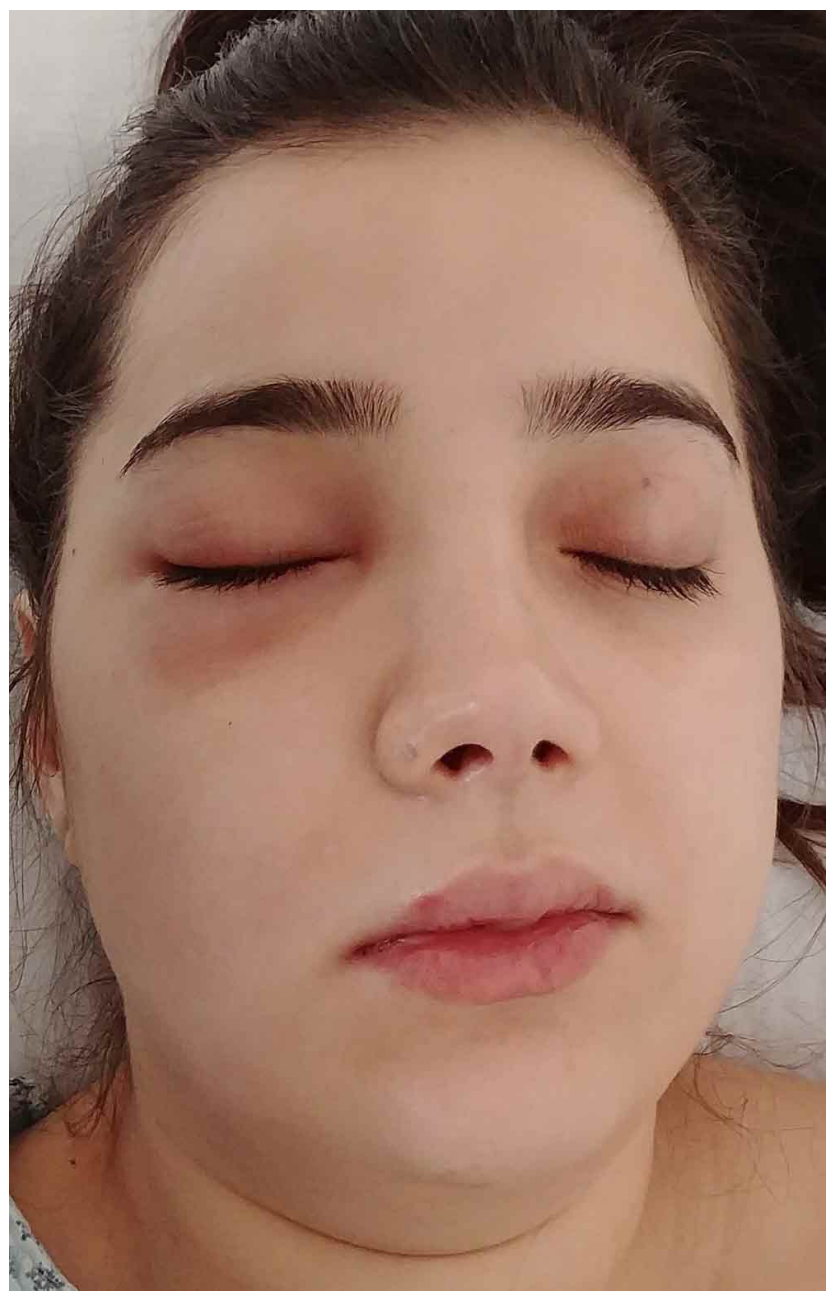

Fig. 1. Case representative of group 1. A 22-year-old female patient presenting an infectious process originating from the right upper first molar with involvement of the canine space. After draining the space involved, remained hospitalized for two days. 


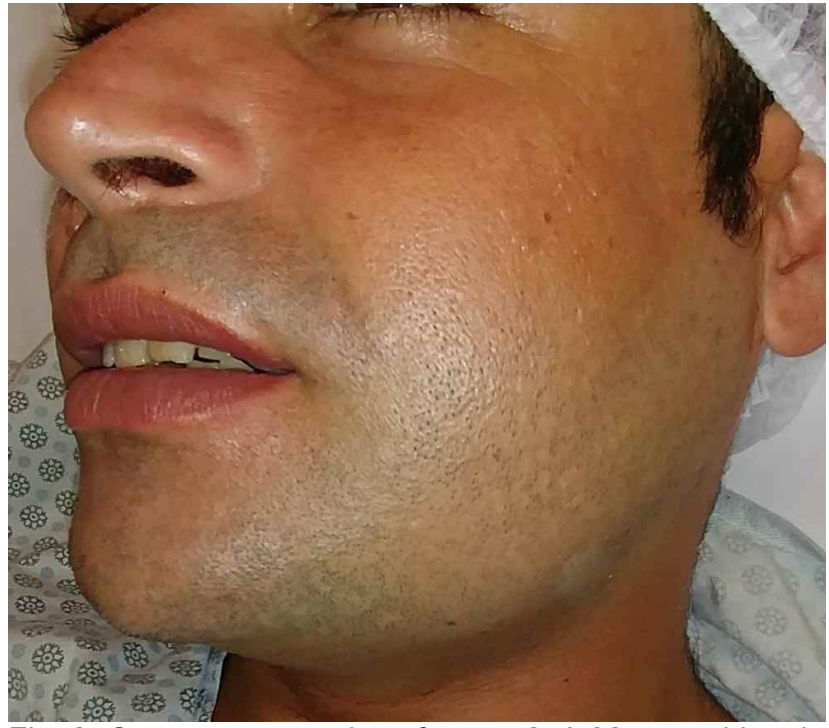

Fig. 2. Case representative of group 2. A 32-year-old male patient presenting with an infectious process originating from the left lower third molar with involvement of the submandibular, pterygomandibular and lateropharyngeal spaces. After draining the spaces involved, remained hospitalized for six days.

The Mann-Whitney or Fisher's exact test was applied to verify a possible difference between the two groups studied for the variables age and sex. The Mann-Whitney test was applied to verify a possible difference between the two groups for the variables related to affected fascial spaces, vital signs and laboratory tests. Spearman's correlation analysis was performed to verify the degree of relationship between length of hospital stay and variables related to vital signs and laboratory tests. Finally, simple regression analysis of the hospitalization time was made in relation to the variables related to vital signs and laboratory tests. SPSS (Statistical Package for Social Sciences, IBM Software Group, Chicago, IL, USA), version 24.0, was used to perform the statistical analyses.

\section{RESULTS}

In this study, 84 cases of maxillofacial infections were detected in the analyzed period and 50 cases of odontogenic infections were included. The mean length of hospital stay was 2.8 days for group 1 and 6.9 days for group 2. The distribution of patients according to mean age and sex is shown in Table I. The mean age was 30.1 years for group 1 and 32.0 for group 2, and there was no significant difference between groups. There was a predominance of male sex in both groups
Table I. Distribution of patients relative to mean age and sex according to groups and statistical significance $(n=50)$.

\begin{tabular}{lccc}
\hline Variable & $\begin{array}{c}\text { Group 1 } \\
(\mathrm{n}=17)\end{array}$ & $\begin{array}{c}\text { Group 2 } \\
(\mathrm{n}=33)\end{array}$ & $\begin{array}{c}\mathrm{P} \text { value } \\
0.608(\mathrm{a})\end{array}$ \\
\hline Mean age \pm s.d. (y) & $30.1 \pm 15.7$ & $32.0 \pm 15.6$ & \\
Sex $\mathrm{n}(\%)$ & & & \\
Male & $11(64.7)$ & $22(66.7)$ & \\
Female & $6(35.3)$ & $11(33.3)$ & $0.890(\mathrm{~b})$ \\
\hline s.d.= standard deviation. (a)= Mann-Whitney test; (b)= Fisher's exact
\end{tabular}
test.

in the approximate ratio of 2: 1 with no significant difference between groups.

The risk factors detected were: diabetes mellitus, two cases (4.0\%); smoking, seven cases (14.0\%); and drug abuse, two cases $(4.0 \%)$. We should note that all the cases of diabetes mellitus and drug abuse and many of the smoking cases were in Group 2.

Signs and symptoms reported by patients at hospital admission were (in decreasing order): trismus (22.4 \% in Group 1, $72.7 \%$ in Group 2), severe edema (25.3\% in Group 1, $57.6 \%$ in Group 2), dysphagia (22.5\% in Group 1, $42.4 \%$ in Group 2) and fever (29.4 $\%$ in Group 1, $39.4 \%$ in Group 2). Dysphagia and voice alterations were reported by only one patient in Group $2(2.0 \%)$. In all analyzed items, the highest frequencies were in Group 2.

Mandibular teeth were the major cause of infection, in a ratio of 4: 1 to maxillary teeth. Specifically, the lower molars affected 37 patients $(74.0 \%)$ in the study. When the infection came from the upper teeth, molars were also the main cause in six patients (12.0 $\%)$. The presence of multiple foci of infection, comprising more than one dental element, was found in only one patient in Group 2.

With regard to the affected fascial spaces, infection was restricted to primary fascial spaces in 37 patients (74.0 \%), 15 in Group $1(88.2 \%)$ and 22 in Group $2(66.6 \%)$. Invasion of secondary or deep fascial spaces affected 13 patients (26.0\%), two in Group 1 $(11.8 \%)$ and 11 in Group 2 (33.3 \%). The distribution of fascial spaces involved according to groups is shown in Table II. Only the total of spaces showed a significant difference between the groups $(p=0.009)$, including spaces that were present in both groups. Other spaces were involved only in group 2, such as: 9 cases in the submental, 6 in the lateropharyngeal, 4 in the pterygomandibular, 3 in the infratemporal, 3 in the retropharyngeal, 2 in the pre-tracheal and 1 in the mediastinum. 
PAVAN, E. P.; ROCHA-JUNIOR, W. G. P. ; GITT, H. A. \& LUZ, J. G. C. Changes in vital signs and laboratory tests in patients with odontogenic infections requiring hospitalization. Int. J. Odontostomat., 14(4):685-693, 2020.

The treatment performed in the majority of cases was drainage of the affected fascial spaces and antibiotic therapy (90\%). Local anesthesia was used in 27 patients (12 in Group 1 and 15 in Group 2 and general anesthesia in 23 patients (5 in Group 1 and 18 in Group 2). Only two patients $(4 \%)$ needed a tracheostomy for maintenance of the airways. Five patients in Group $2(10 \%)$ had spontaneous drainage after drug action with subsequent surgical drainage.

The mean values of vital signs measured at hospital admission according to each group are presented in Table III. Only heart rate values showed a significant difference between the groups $(p=0.012)$.

The mean values of the laboratory tests obtained at hospital admission according to each group are presented in Table IV. All the mean values of Group 2 were higher in relation to Group 1. The items leukocytes $(p=0.037)$, neutrophils
Table II. Distribution of fascial spaces involved according to groups and the significance of the Mann-Whitney test.

\begin{tabular}{|c|c|c|c|c|c|}
\hline Fascial space & Group & $\mathrm{n}$ & Mean & Standard & $P$ value \\
\hline \multirow[t]{3}{*}{ Canine } & 1 & 5 & 1,00 & 0,00 & $>0.999$ \\
\hline & 2 & 1 & 1,00 & 0,00 & \\
\hline & Total & 6 & 1,00 & 0,00 & \\
\hline \multirow[t]{3}{*}{ Buccal } & 1 & 7 & 1,00 & 0,00 & $>0.999$ \\
\hline & 2 & 11 & 1,00 & 0,00 & \\
\hline & Total & 18 & 1,00 & 0,00 & \\
\hline \multirow[t]{3}{*}{ Sublingual } & 1 & 1 & 1,00 & 0,00 & 0.480 \\
\hline & 2 & 8 & 1,38 & 0,52 & \\
\hline & Total & 9 & 1,33 & 0,50 & \\
\hline \multirow[t]{3}{*}{ Submandibular } & 1 & 10 & 1,00 & 0,00 & 0.364 \\
\hline & 2 & 25 & 1,08 & 0,28 & \\
\hline & Total & 35 & 1,06 & 0,24 & \\
\hline \multirow[t]{3}{*}{ Masseteric } & 1 & 2 & 1,00 & 0,00 & $>0.999$ \\
\hline & 2 & 6 & 1,00 & 0,00 & \\
\hline & Total & 8 & 1,00 & 0,00 & \\
\hline \multirow[t]{3}{*}{ Total of spaces } & 1 & 17 & 1,47 & 0,62 & 0.009 \\
\hline & 2 & 33 & 2,55 & 1,73 & \\
\hline & Total & 50 & 2,18 & 1,54 & \\
\hline
\end{tabular}

$(p=0.021), N / L$ ratio $(p=0.044)$ and CRP $(p=0.004)$ had statistically significant differences between groups. Only the ESR values did not have statistical significance when compared between groups.

Table III. Mean values of vital signs presented by patients at hospital admission according to the groups and the significance of the Mann-Whitney test.

\begin{tabular}{|c|c|c|c|c|c|c|}
\hline Variable & Group & Mean & Standard-deviation & Minimum & Maximum & $P$ value \\
\hline \multirow[t]{2}{*}{ Body temperature $\left({ }^{\circ} \mathrm{C}\right)$} & 1 & 36.35 & 0.40 & 36.00 & 37.00 & 0.215 \\
\hline & 2 & 36.54 & 0.49 & 35.80 & 37.60 & \\
\hline \multirow[t]{2}{*}{ Heart rate $(\mathrm{bpm})$} & 1 & 80.82 & 12.22 & 58.00 & 114.00 & 0.012 \\
\hline & 2 & 90.61 & 13.09 & 66.00 & 119.00 & \\
\hline \multirow[t]{2}{*}{ Respitaory rate (rpm) } & 1 & 18.36 & 1.96 & 16.00 & 22.00 & 0.126 \\
\hline & 2 & 20.38 & 3.88 & 14.00 & 29.00 & \\
\hline \multirow[t]{2}{*}{ Systolic blood pressure (mmHg) } & 1 & 131.40 & 20.36 & 90.00 & 160.00 & 0.454 \\
\hline & 2 & 126.50 & 14.30 & 94.00 & 150.00 & \\
\hline \multirow[t]{2}{*}{ Diastolic blood pressure $(\mathrm{mmHg})$} & 1 & 81.67 & 13.97 & 60.00 & 100.00 & 0.393 \\
\hline & 2 & 78.14 & 11.38 & 57.00 & 109.00 & \\
\hline
\end{tabular}

Table IV. Mean values of the laboratory tests of patients at hospital admission according to the groups and the significance of the Mann-Whitney test.

\begin{tabular}{|c|c|c|c|c|c|c|}
\hline Variable & Group & Mean & Standard-deviation & Minimum & Maximum & $\mathrm{P}$ value \\
\hline \multirow[t]{2}{*}{ Leucocytes $\left(\times 10^{3 /} \mu \mathrm{L}\right)$} & 1 & 12.05 & 3.57 & 7.10 & 20.80 & 0.037 \\
\hline & 2 & 15.58 & 5.84 & 7.10 & 30.00 & \\
\hline \multirow[t]{2}{*}{ Neutrophils $\left(\times 10^{3 /} \mu \mathrm{L}\right)$} & 1 & 8.83 & 2.80 & 4.74 & 15.18 & 0.021 \\
\hline & 2 & 12.44 & 5.53 & 4.66 & 25.08 & \\
\hline \multirow[t]{2}{*}{$\mathrm{N} / \mathrm{L}$ ratio } & 1 & 4.63 & 2.07 & 1.68 & 11.00 & 0.044 \\
\hline & 2 & 7.09 & 4.45 & 2.16 & 21.80 & \\
\hline \multirow[t]{2}{*}{ CRP (mg/L) } & 1 & 63.18 & 62.99 & 9.00 & 272.00 & 0.004 \\
\hline & 2 & 117.06 & 72.25 & 7.00 & 252.00 & \\
\hline \multirow[t]{2}{*}{$\operatorname{ESR}(\mathrm{mm} / 1 \mathrm{~h})$} & 1 & 53.55 & 32.55 & 9.00 & 115.00 & 0.825 \\
\hline & 2 & 56.83 & 29.06 & 7.00 & 105.00 & \\
\hline
\end{tabular}


There was a positive and statistically significant correlation between the length of hospital stay and the variables of heart rate $(p=0.028)$, leukocytosis $(p=$ $0.045)$, neutrophilia $(p=0.033), N / L$ ratio $(p=0.041)$ and CRP level $(p=0.003)$ (Table V).
Next, only the regression analyses (in the form of graphs, equations and R2) of the factors in which there was a significant Spearman correlation with the length of hospital stay were presented, since in general the $\mathrm{R} 2$ values were relatively low for all comparisons. The analysis of the numbers obtained in decreasing order indicates that $29.0 \%$ of the variation in hospital stay time was due to an increase in the $\mathrm{N} / \mathrm{L}$ ratio (Fig. 3), $21.8 \%$ was due to neutrophilia (Fig. 4), $19.0 \%$ was due to leukocytosis (Fig. 5), $16.4 \%$ was due to increased heart rate (Fig. 6), and $11.5 \%$ due to increased CRP (Fig. 7) levels.
Diastolic blood pressure

Leukocytes

Neutrophils

$\mathrm{N} /$ L ratio

CRP

ESR

$\begin{array}{cc}\text { Statistics } & \text { Length of stay (days) } \\ \text { Correlation coefficient }(r) & +0.092 \\ \text { P value } & 0.525 \\ \text { Correlation coefficient }(r) & +0.311 \\ \text { P value } & 0.028 \\ \text { Correlation coefficient }(r) & +0.307 \\ \text { P value } & 0.087 \\ \text { Correlation coefficient }(r) & -0.107 \\ \text { P value } & 0.493 \\ \text { Correlation coefficient }(r) & -0.151 \\ \text { P value } & 0.333 \\ \text { Correlation coefficient }(r) & +0.284 \\ \text { P value } & 0.045 \\ \text { Correlation coefficient }(r) & +0.302 \\ \text { P value } & 0.033 \\ \text { Correlation coefficient }(r) & +0.291 \\ \text { P value } & 0.041 \\ \text { Correlation coefficient }(r) & +0.426 \\ \text { P value } & 0.003 \\ \text { Correlation coefficient }(r) & +0.026 \\ \text { P value } & 0.886\end{array}$

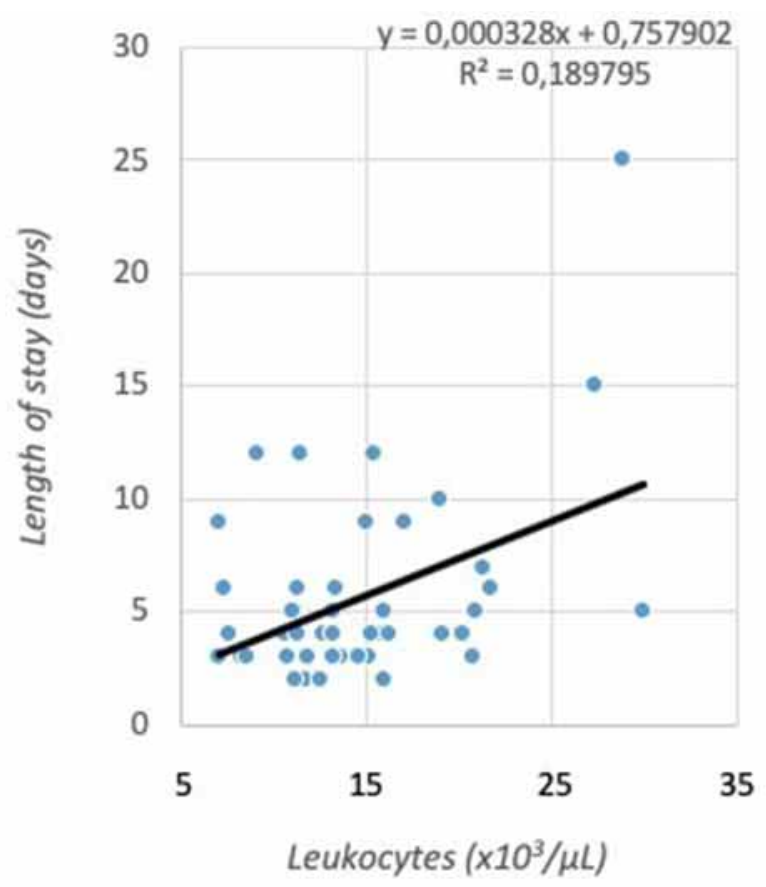

Fig. 4. Application of the simple regression analysis between the variables length of hospital stay and leukocytes.
Fig. 3. Application of the simple regression analysis between the variables length of hospital stay and preoperative heart rate.

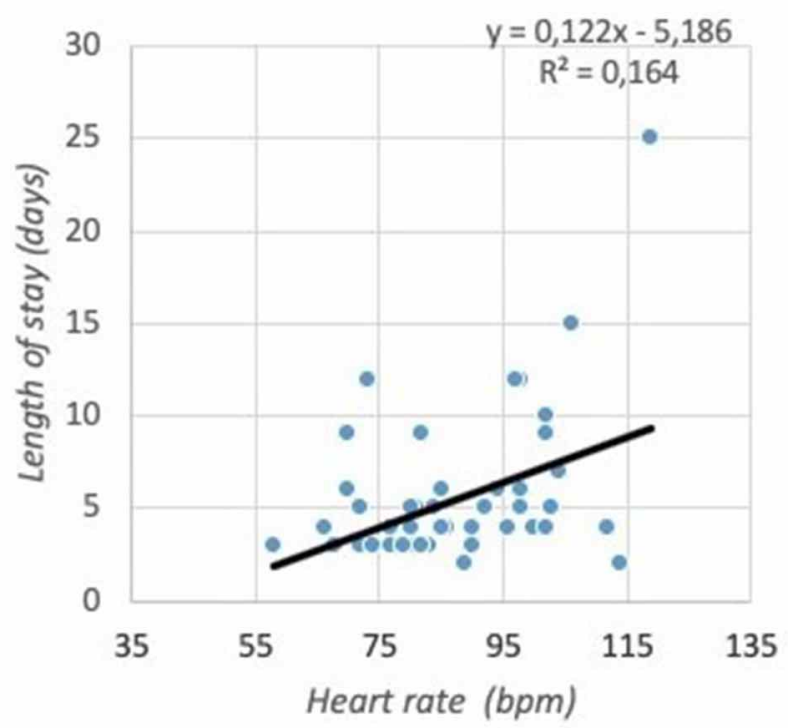




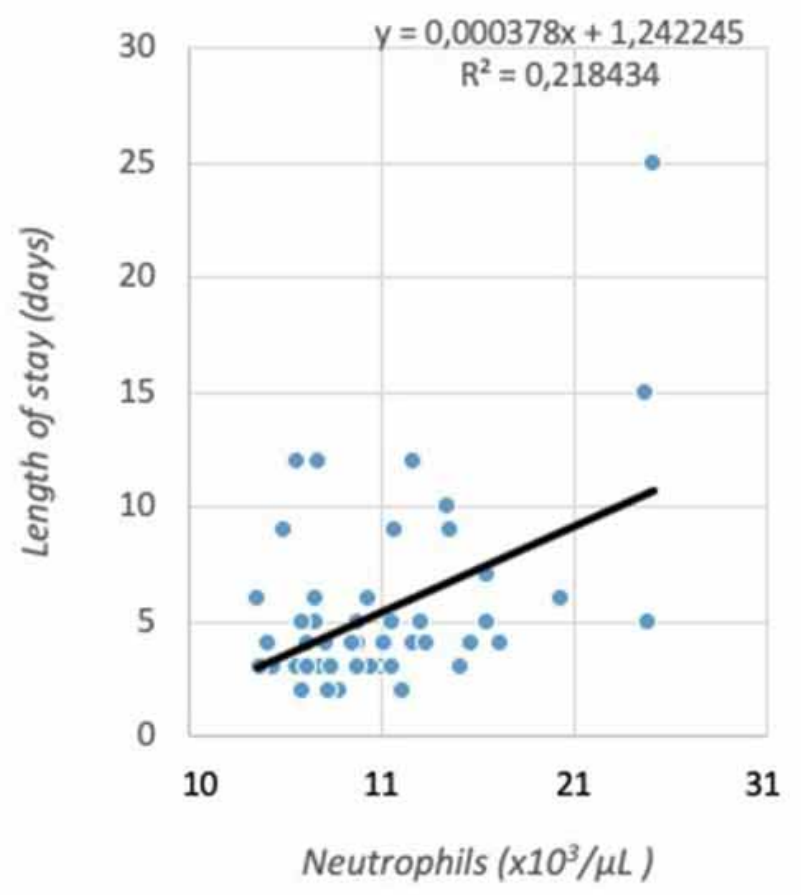

Fig. 5. Application of the simple regression analysis between the variables length of hospital stay and neutrophils.

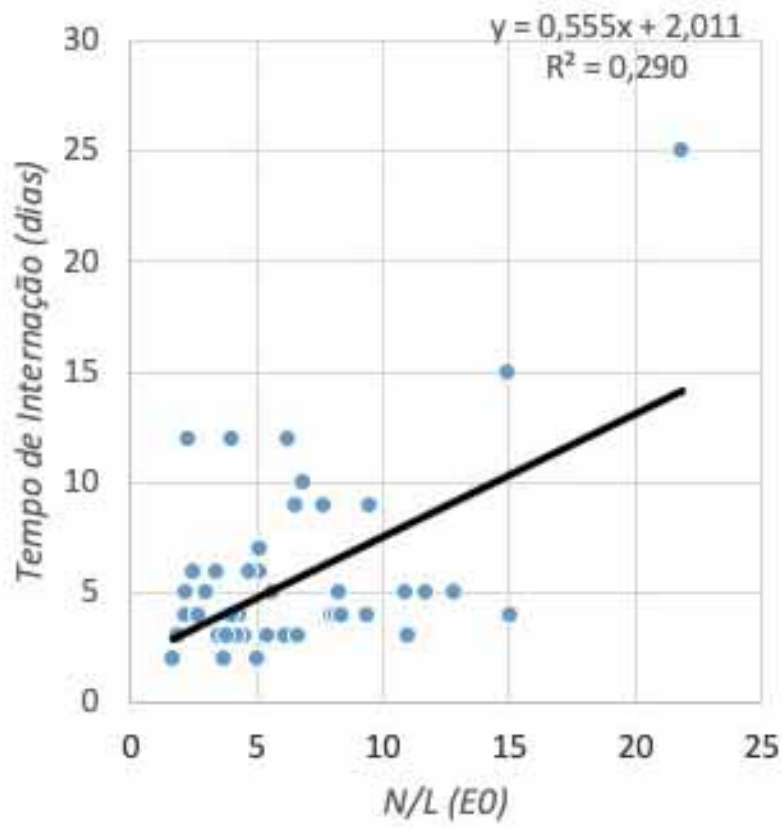

Fig. 6. Application of the simple regression analysis between the variables length of hospital stay and neutrophil/ lymphocyte $(\mathrm{N} / \mathrm{L})$ ratio.

\section{DISCUSSION}

This study evaluated the changes in vital signs and laboratory tests of patients with odontogenic

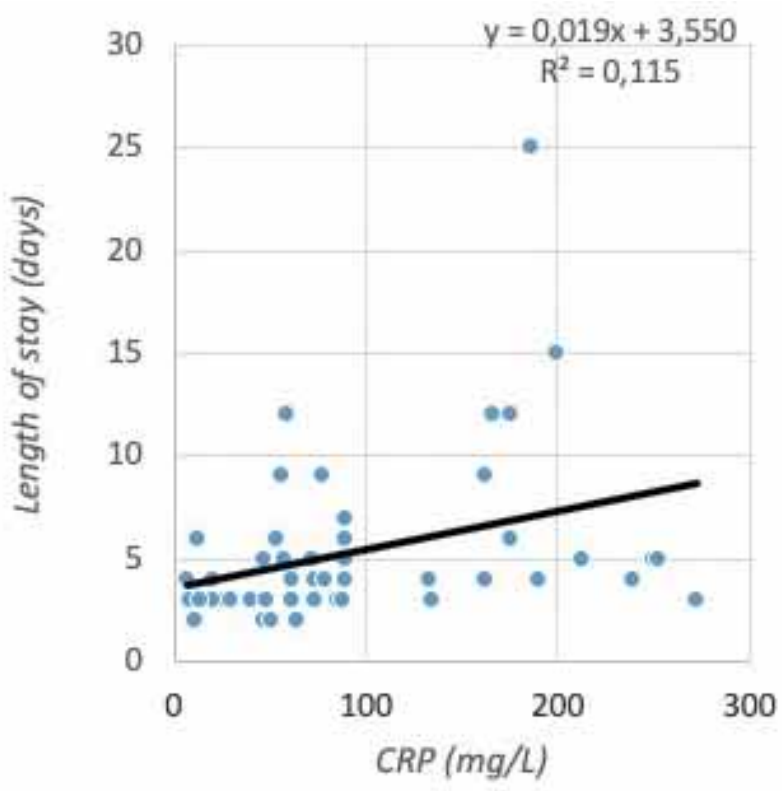

Fig. 7. Application of the simple regression analysis between the variables length of hospital stay and C-reactive protein (CRP).

infections who required hospitalization and verified their efficacy in the ability to define the severity of the presented case. It was found that there were significant increases in heart rate, leukocytosis, neutrophilia, N/L ratio, and CRP levels for complex cases. Additionally, there were positive and statistically significant correlations between the length of hospital stay and variables, such as heart rate, leukocytosis, neutrophilia, $\mathrm{N} / \mathrm{L}$ ratio and CRP level.

The mean age found in both groups fluctuated in the early years of the fourth decade of life (with no significant difference), being in agreement with other studies (Flynn et al., 2006; Stathopoulos et al.; S, entürk et al., 2016). One study points out that adults in the 31-50 age range are more prone to neglect oral health (Mathew et al., 2012). In our study, there was a greater predominance of males in both groups, in the approximate ratio of $2: 1$. Studies have also found a higher proportion of cervicofacial infections in male patients (Sharma et al.; Alotaibi et al., 2015; Sandner et al., 2015). This higher frequency in males is most likely due to neglect of oral health (Hwang et al., 2011; Mathew et al.).

In general, the signs and symptoms, such as trismus, severe edema, dysphagia, fever and voice alteration, reported by patients at hospital admission were more frequent in Group 2, which showed that the 
classification used (based on hospitalization time) had clinical value. With regard to the fascial spaces affected, the invasion of secondary or deep fascial spaces was more frequent in Group 2.

Patients had a mean hospital stay of 2.8 days for Group 1 and 6.9 days for Group 2. One study showed a mean hospital length of 2.7 days for odontogenic infections (Stathopoulos et al.). Another study showed that the mean length of hospital stay for odontogenic infections was 4.4 days, with cases of Ludwig's angina having a mean of 6.8 days (Gonçalves et al., 2013). One study found that the moderate and severe cases had an average hospital stay of 4.5 days, while the mild cases remained hospitalized for 3 days on average (Mirochnik et al.). A study of patients with odontogenic infections who needed care in intensive care units (ICUs) showed that the mean hospitalization was 7.7 days (Ylijoki et al.). One of the limitations of this study comes from the short hospitalization time of patients in Group 1 , which prevented the execution of new laboratory tests at appropriate intervals for statistical comparison.

It is interesting to note that all of the cases of diabetes mellitus and drug abuse and many of the smoking cases were in Group 2, suggesting that such comorbidities contributed as risk factors to worsening of the cases. Patients with diabetes mellitus require longer hospitalizations due to reduced neutrophil activity in the fight against infections (Rao et al., 2010; Liu et al., 2017). As for smoking, it is unclear how it can influence the immune response to odontogenic infection (Camino Junior et al.). Other comorbidities, such as obesity, immunosuppression, hypertension, drug abuse and poor oral hygiene, also contribute to prolonged hospital stays for odontogenic infections (Opitz et al., 2015).

Trismus, marked edema and dysphagia were the major clinical indicators for hospital admission, and other studies have presented similar results (Boscolo-Rizzo \& Da Mosto, 2009; Hwang et al.; Mathew et al.). The presence of trismus and dysphagia are considered strong indicators of severe odontogenic infection due to their effect on the masticatory space and upper airway, respectively (Mathew et al.; Gonçalves et al.).

Most patients were treated with the drainage of affected fascial spaces and antibiotic therapy, which is considered the most effective therapy (Bali et al.; Gonçalves et al.; Opitz et al.). The high success rate of treatment is due to the rapid intervention in the infectious process (Mathew et al.; Han et al., 2016). Another limitation of this study is the collection of material for microbiological examination, which proved to be ineffective, because routine laboratory anaerobic culture, as well as the difficulty in collecting anaerobes. However, studies have shown that microorganism culture shows little therapeutic value in the management of localized maxillofacial infections, and surgical therapy and removal of the infectious focus are of paramount importance (Mathew et al.; Kumari et al., 2018).

In $74 \%$ of the patients studied, the lower molars were the main infectious focus. The lower molars, especially the third molars, are considered to be the major cause of odontogenic infections, with dissemination to the deep cervical spaces due to the root position and its relation with the insertion of the mylohyoid muscle (Sánchez et al., 2011; Opitz et al.). A study on odontogenic infections with a high risk of spreading to the cervical spaces found that the cases that needed support in ICUs were derived from mandibular tooth infections (Alotaibi et al.).

Regarding the mean values of vital signs, only the heart rate showed a significant difference between the groups (with higher values for Group 2) and a positive and statistically significant correlation in relation to the length of hospital stay. Some studies use indices to determine the prognosis of odontogenic infections, which include heart rate as one of the parameters to estimate disease severity. On a clinical severity scale of these infections, the heart rate is within the systemic parameters (Bali et al.). An increase in heart rate is among the factors that are part of the systemic inflammatory response syndrome, which is one of the domains of another index proposed for such infections (Sainuddin et al., 2017).

Regarding laboratory tests, the values of leukocytes, neutrophils and N/L ratio showed a significant difference between the groups and a positive and statistically significant correlation in relation to the time of hospitalization. The greater the severity of the case is, the greater its values will be in the laboratory tests and, consequently, the longer the hospital stay will be, also serving to determine the efficacy of antibiotic therapy. The leukocyte count and left shift show the course of bacterial infection from baseline to recovery. Left shift demonstrates the need for neutrophils to combat infection, and white blood cell count shows the ability of the bone marrow to deliver neutrophils in real time (Ishimine et al., 2013). Time-series data of left shift and white blood cell count allows more accurate evaluation of the condition of a patient with bacterial infection (Honda et al.). 
The inflammatory response in the body during bacterial infections is characterized by neutrophilia and lymphocytopenia. This relationship between inflammatory cells is verified by the $\mathrm{N} / \mathrm{L}$ ratio, which has been shown to be an efficient marker used in the routine diagnosis of bacterial infections $(S$, entürk et al.). Under physiological conditions, the factor N/L ratio is less than or equal to 5 , and under conditions of infection/severe inflammation, the value is greater than 6 (Zahorec, 2001). Our study showed a mean value of 4.6 for group 1 and 7.1 for group 2, with a statistically significant difference between groups. Another study has demonstrated the effectiveness of the $N / L$ ratio as a prognostic marker of odontogenic infections and its correlation with length of hospital stay (Dogruel et al.).

Our study showed a strong positive correlation between CRP levels and length of hospital stay and a significant difference between groups. CRP levels increase 4 to 6 hours after injury, reaching a peak between 24 and 48 hours. CRP values regress rapidly when the inflammatory condition is resolved, showing more sensitivity than the leukogram and ESR (Ylijoki et al.; Ren \& Malmstrom, 2007; Schmit \& Vincent, 2008). It is worth noting, however, that CRP values are not able to determine the course of the infection in real time, because they are low in the initial phase and remain above reference after recovery (Ishimine et al.).

There was no significant difference in the ESR values when comparing the groups, and no correlation with the length of hospital stay was observed. Studies on osteoarticular infections have shown the value of ESR as a marker. ESR and CRP levels are highly sensitive in pediatric patients with osteoarticular infections, such as septic arthritis and osteomyelitis. ESR is recommended as an entry inflammatory marker, whereas CRP can be used to monitor the course of infection (Pääkkönen et al., 2010; Hariharan \& Kabrhel, 2011).

\section{CONCLUSION}

In this study with patients with odontogenic infections who required hospitalization there were significant increases in heart rate, leukocytosis, neutrophilia, N/L ratio and CRP levels for the complex cases. There were also positive correlations between the length of stay and the following variables: heart rate, leukocytosis, neutrophilia, N/L ratio and CRP level.
PAVAN, E. P.;ROCHA-JUNIOR, W. G. P. ; GITT, H. A. \& LUZ, J. G. C. Cambios en los signos vitales y pruebas de laboratorio en pacientes con infecciones odontogénicas que requirieron hospitalización. Int. J. Odontostomat., 14(4):685693, 2020.

RESUMEN: El propósito de este estudio fue evaluar los cambios en los signos vitales y las pruebas de laboratorio de pacientes con infecciones odontogénicas que requirieron hospitalización, así como verificar su efectividad para determinar la gravedad del caso y las posibles correlaciones con la duración de la internación. Pacientes con infecciones odontogénicas que requirieron hospitalización fueron evaluados prospectivamente entre octubre de 2016 y abril de 2018. Los pacientes se dividieron en dos grupos considerados como casos simples (Grupo 1) o complejos (Grupo 2) según la duración de la internación. Se analizaron los datos personales, comorbilidades, signos y síntomas, signos vitales y pruebas de laboratorio. En este estudio, se detectaron 84 casos de infecciones maxilofaciales y se incluyeron 50 casos de infecciones odontogénicas. Hubo aumentos significativos en la frecuencia cardíaca $(p=0,012)$, leucocitosis $(p=0,037)$, neutrofilia $(p=0,021)$, relación neutrófilos / linfocitos $(N / L)(p=0,044)$ y niveles de proteína $C$ reactiva $(P C R)(p=0,004)$ en el Grupo 2. Además, hubo correlaciones positivas entre la duración de la internación y las siguientes variables: frecuencia cardíaca $(p=0,028)$, leucocitosis $(p=0,045)$, neutrofilia $(p=0,033)$, relación $N / L$ $(p=0,041)$ y nivel de PCR $(p=0,003)$. Se encontró que la relación $\mathrm{N} / \mathrm{L}$ tenía un mayor valor en el análisis de regresión. En conclusión, hubo aumentos significativos en la frecuencia cardíaca, leucocitosis, neutrofilia, relación N/L y niveles de PCR para los casos complejos. También hubo correlaciones positivas entre la duración de la internación y las siguientes variables: frecuencia cardíaca, leucocitosis, neutrofilia, relación N/L y nivel de PCR.

PALABRAS CLAVE: infecciones odontogénicas, infecciones bacterianas, hospitalización, signos vitales, recuento de células sanguíneas.

\section{REFERENCES}

Aguiar, F. J. B.; Ferreira-Junior, M.; Sales, M. M.; Cruz-Neto, L. M.; Fonseca, L. A. M.; Sumita, N. M.; Duarte, N. J. C.; Lichtenstein, A. \& Duarte, A. J. S. C-reactive protein: clinical applications and proposals for a rational use. Rev. Assoc. Med. Bras. (1992), 59(1):85-92, 2013.

Alotaibi, N.; Cloutier, L.; Khaldoun, E.; Bois, E.; Chirat, M. \& Salvan, $D$. Criteria for admission of odontogenic infections at high risk of deep neck space infection. Eur. Ann. Otorhinolaryngol. Head Neck Dis., 132(5):261-4, 2015.

Bali, R.; Sharma, P.; Ghanghas, P.; Gupta, N.; Tiwari, J. D.; Singh, A.; Sapra, N. \& Goyal, D. To compare the efficacy of c-reactive protein and total leucocyte count as markers for monitoring the course of odontogenic space infections. J. Maxillofac. Oral Surg., 16(3):322-7, 2017. 
PAVAN, E. P.; ROCHA-JUNIOR, W. G. P. ; GITT, H. A. \& LUZ, J. G. C. Changes in vital signs and laboratory tests in patients with odontogenic infections requiring hospitalization. Int. J. Odontostomat., 14(4):685-693, 2020.

Boscolo-Rizzo, P. \& Da Mosto, M. C. Submandibular space infection: a potentially lethal infection. Int. J. Infect. Dis., 13(3):327-33, 2009.

Camino Junior, R.; Naclerio-Homem, M. G.; Cabral, L. M. \& Luz, J. G. C. Cervical necrotizing fasciitis of odontogenic origin in a diabetic patient complicated by substance abuse. Braz. Dent. J., 25(1):6972, 2014.

Dogruel, F.; Gonen, Z. P.; Gunay-Canpolat, D.; Zararsiz, G. \& Alkan, A. The Neutrophil-to-Lymphocyte ratio as a marker of recovery status in patients with severe dental infection. Med. Oral Patol. Oral Cir. Bucal, 22(4):e440-5, 2017.

Flynn, T. R.; Shanti, R. M.; Levi, M. H.; Adamo, A. K.; Kraut, R. A. \& Trieger, N. Severe odontogenic infections, part 1: prospective report. J. Oral Maxillofac. Surg., 64(7):1093-103, 2006.

Gonçalves, L.; Lauriti, L.; Yamamoto, M. K. \& Luz, J. G. C. Characteristics and management of patients requiring hospitalization for treatment of odontogenic infections. J. Craniofac. Surg., 24(5):e458-62, 2013.

Han, X.; An, J.; Zhang, Y.; Gong, X. \& He, Y. Risk factors for lifethreatening complications of maxillofacial space infection. $J$. Craniofac. Surg., 27(2):385-90, 2016.

Hariharan, P. \& Kabrhel, C. Sensitivity of erythrocyte sedimentation rate and $\mathrm{C}$-reactive protein for the exclusion of septic arthritis in emergency department patients. J. Emerg. Med., 40(4):428-31, 2011.

Honda, T.; Uehara, T.; Matsumoto, G.; Arai, S. \& Sugano, M. Neutrophil left shift and white blood cell count as markers of bacterial infection. Clin. Chim. Acta., 457:46-53, 2016.

Hwang, T.; Antoun, J. S. \& Lee, K. H. Features of odontogenic infections in hospitalised and non-hospitalised settings. Emerg. Med. J., 28(9):766-9, 2011.

Ishimine, N.; Honda, T.; Yoshizawa, A.; Kawasaki, K.; Sugano, M.; Kobayashi, Y. \& Matsumoto, T. Combination of white blood cell count and left shift level real-timely reflects a course of bacterial infection. J. Clin. Lab. Anal., 27(5):407-11, 2013.

Kumari, S.; Mohanty, S.; Sharma, P.; Dabas, J.; Kohli, S. \& Diana, C. Is the routine practice of antibiotic prescription and microbial culture and antibiotic sensitivity testing justified in primary maxillofacial space infection patients? A prospective, randomized clinical study. J. Craniomaxillofac. Surg., 46(3):446-52, 2018.

Liu, Y. H.; Su, H. H.; Tsai, Y. W.; Hou, Y. Y.; Chang, K. P.; Chi, C. C.; Lin, M. Y. \& Wu, P. H. Initial factors influencing duration of hospital stay in adult patients with peritonsillar abscess. Clin. Exp. Otorhinolaryngol., 10(1):115-20, 2017.

Mathew, G. C.; Ranganathan, L. K.; Gandhi, S.; Jacob, M. E.; Singh, I.; Solanki, M. \& Bither, S. Odontogenic maxillofacial space infections at a tertiary care center in North India: a five-year retrospective study. Int. J. Infect. Dis., 16(4):e296-302, 2012.

Mirochnik, R.; Araida, S.; Yaffe, V. \& Abu El-Naaj, I. C-reactive protein concentration as a prognostic factor for inflammation in the management of odontogenic infections. Br. J. Oral Maxillofac. Surg., 55(10):1013-7, 2017.

Opitz, D.; Camerer, C.; Camerer, D. M.; Raguse, J. D.; Menneking, H.; Hoffmeister, B. \& Adolphs, N. Incidence and management of severe odontogenic infections-a retrospective analysis from 2004 to 2011. J. Craniomaxillofac. Surg., 43(2):285-9, 2015.

Pääkkönen, M.; Kallio, M. J. T.; Kallio, P. E. \& Peltola, H. Sensitivity of erythrocyte sedimentation rate and C-reactive protein in childhood bone and joint infections. Clin. Orthop. Relat. Res., 468(3):861-6, 2010.

Rao, D. D.; Desai, A.; Kulkarni, R. D.; Gopalkrishnam, K. \& Rao, C. B. Comparison of maxillofacial space infection in diabetic and nondiabetic patients. Oral Surg. Oral Med. Oral Pathol. Oral Radiol. Endod., 110(4):e7-12, 2010.

Ren, Y. F. \& Malmstrom, H. S. Rapid quantitative determination of Creactive protein at chair side in dental emergency patients. Oral Surg. Oral Med. Oral Pathol. Oral Radiol. Endod., 104(1):49-55, 2007.
Sainuddin, S.; Hague, R.; Howson, K. \& Clark, S. New admission scoring criteria for patients with odontogenic infections: a pilot study. Br. J. Oral Maxillofac. Surg., 55(1):86-9, 2017.

Sánchez, R.; Mirada, E.; Arias, J.; Paño, J. R. \& Burgueño, M. Severe odontogenic infections: epidemiological, microbiological and therapeutic factors. Med. Oral Patol. Oral Cir. Bucal, 16(5):e6706, 2011.

Sandner, A.; Moritz, S.; Unverzagt, S.; Plontke, S. K. \& Metz, D. Cervical necrotizing fasciitis--The value of the laboratory risk indicator for necrotizing fasciitis score as an indicative parameter. J. Oral Maxillofac. Surg., 73(12):2319-33, 2015.

Schmit, X. \& Vincent, J. L. The time course of blood C-reactive protein concentrations in relation to the response to initial antimicrobial therapy in patients with sepsis. Infection, 36(3):213-9, 2008.

S, entürk, M.; Azgın, I' .; Övet, G.; Alatas, N.; Ag ırgöl, B. \& Yılmaz, $E$. The role of the mean platelet volume and neutrophil-tolymphocyte ratio in peritonsillar abscesses. Braz. J. Otorhinolaryngol., 82(6):662-7, 2016.

Sharma, A.; Giraddi, G.; Krishnan, G. \& Shahi, A. K. Efficacy of serum prealbumin and CRP levels as monitoring tools for patients with fascial space infections of odontogenic origin: a clinicobiochemical study. J. Maxillofac. Oral Surg., 13(1):1-9, 2014.

Stathopoulos, P.; Igoumenakis, D.; Shuttleworth, J.; Smith, W. \& Ameerally, P. Predictive factors of hospital stay in patients with odontogenic maxillofacial infections: the role of C-reactive protein. Br. J. Oral Maxillofac. Surg., 55(4):367-70, 2016.

Ylijoki, S.; Suuronen, R.; Jousimies-Somer, H.; Meurman, J. H. \& Lindqvist, $C$. Differences between patients with or without the need for intensive care due to severe odontogenic infections. $J$. Oral Maxillofac. Surg., 59(8):867-72, 2001.

Zahorec, R. Ratio of neutrophil to lymphocyte counts--rapid and simple parameter of systemic inflammation and stress in critically ill. Bratisl. Lek. Listy, 102(1):5-14, 2001.

Corresponding author:

João Gualberto C. Luz

Rua Duarte de Azevedo 284 - cj. 22

02036-021, São Paulo, SP

BRAZIL

Email:jgcluz@usp.br

Received: 03-04-2020

Accepted: 04-07-2020 